\title{
Growth Response of in vitro regenerated Drymaria cordata (L.) Willd. ex Roem. \& Schult. to inoculation with Arbuscular Mycorrhizal fungi
}

\author{
Indira $\mathrm{M} \mathrm{N}^{1 *}$ and Tejavathi $\mathrm{D} \mathrm{H}^{2}$ \\ ${ }^{1}$ Department of Life Sciences, Kristu Jayanti College, Bangalore \\ ${ }^{2}$ Department of Botany, Jnana Bharathi Campus, Bangalore University \\ Correspondence audhor: indiramn@gmail.com
}

\begin{abstract}
Drymaria cordata (L.) Willd. ex Roem. \& Schult. commonly known as 'West Indian Chick weed' is a potential herb used in traditional medicine in the treatment of many ailments. The main active principles therapeutically are known as drymaritin and isovitexin. Arbuscular mycorrhizae (AM) are symbiotic associations between plants and soil fungi that play a vital role in plant growth and development as well as soil quality. In the present investigation, an attempt was made to determine the growth responses of in vitro regenerated Drymaria cordata to inoculation with arbuscular mycorrhizal fungi. Both normal and in vitro regenerated plants of Drymaria cordata were inoculated with Glomus mosseae and Glomus fasciculatum. All the inoculated plants showed significant morphological results over control after a period of 30,60 and 90 days of inoculation in polyhouse pot experiment. The percent of colonization and the number of spores in the rhizosphere of the in vitro regenerated plants are significantly more than the normal plants. Inoculation of in vitro regenerated plants with Glomus fasciculatum showed maximum mycorrhizal inoculation effect. Mycorrhizal inoculation significantly increased the biomass, root and shoot length, plant height, leaf area, number of branches, number of nodes per branch and internodal length. Such increases were related to the intensity of mycorrhizal association in the root. These findings indicate that mycorrhizal inoculation can be a suitable and alternative method to improve the growth of Drymaria cordata.
\end{abstract}

KeyWords Arbuscular mycorrhizae, regenerated, rhizosphere, Glomus mosseae, Glomus fasciculatum

\section{Introduction}

The cultivation and propagation of traditionally important medicinal plants has taken a huge leap in recent years due to their tremendous potential in curing a number of human ailments. There is a huge demand for these plant based raw materials in the pharmaceutical industry. Due to its extensive diversity in climatic and edaphic factors, the weed flora widely differs from one region to another due to different seasons, cropping patterns adopted and association with crops. The diversity of symbiotic fungi and the mycorrhizal status of certain medicinal plants have been reported by many workers $(1,2)$. Besides the crop loss aspect of weeds there is another aspect of mycorrhizal association in weeds. It is quite possible that interaction with AMF can increase the beneficial effects of weeds on the functioning of agro-ecosystem (3,4). Majorly $90 \%$ of plant species are associated with Arbuscular Mycorrhizal Fungi (AMF), which are important for accessing and recycling nutrients, improve the quality of soil by influencing its structure and texture, and hence plant health $(5,6)$. Only few plants develop normally without mycorrhiza. These non- pathogenic relationships are geographically ubiquitous. The extent of plant growth promotion by AM fungi depends upon specific plant and fungal combinations.

Formation of hyphal network by the AMF with plant roots in known to enhance the access of roots to a large surface area of the soil, causing improvement in plant growth. AM fungi are known to improve the plant growth through better uptake of water and nutrients, particularly phosphorus and also increases host tolerance to pathogens, stress and drought. $(7,8,9,10)$ Mycorrhization of tissue-cultured propagules has the potential to produce plants with increased levels of biologically active secondary metabolites(11).

The current investigation was under taken to examine the response of $A M$ fungi on colonization and morphological variations in Drymaria cordata, a commonly occurring medicinal weed in the coffee plantations. The herb Drymaria cordata, is used by the tribes across India and other countries in treating a number of human ailment $(12,13,14)$. Many biological active compounds have been isolated from this plant including drymaritin and isovitexin, which have been used in chemotheraphy against many types of diseases (15). Due to wide application of medicinal plants in various treatments, it is therefore imperative to enhance their biomass production and quality in order to fulfill societal demands. The present study is the foremost attempt to introduce arbuscualr mycorrhizae in micropropagated plants of Drymaria cordata.

\section{Materials and Methods}

The study was undertaken in the polyhouse of Botany Department, Bangalore University. The regenerated plants of Drymaria cordata were obtained through indirect organogenesis from nodal explants cultured on MS basal medium supplemented with BAP (4.44 $\mu \mathrm{M}), \mathrm{GA} 3(1.44 \mu \mathrm{M})$ and 2,4-D $(2.26 \mu \mathrm{M})$. In vitro 
regenerated shoots were separated and inoculated on MS medium containing IBA $(0.49 \mu \mathrm{M})$ for root induction. The hardened and acclimatized two month old regenerated plants were taken for AM studies along with two month old normal plants. The percentage of root colonization, spore count and morphological studies, in the untreated and treated normal and regenerated plants were carried out at an interval of 30,60 and 90 days and results were tabulated.

\section{Inoculants used}

Two species of AM fungi namely Glomus fasciculatum (Thaxter) and Glomus mosseae (Nicol. \& Gerd.) Gerd. and Trappe were used in the study. The inoculums were procured from the Department of Microbiology, University of Agricultural Sciences, GKVK Campus, Bangalore. The inoculums consisted of sand soil mixture containing extrametrical spores and extrametrical mycelia of Glomus mosseae and Glomus fasciculatum along with root segments of Rhodes grass as host for mycorrhizal fungi.

\section{Preparation for Pot culture experiment}

For pot culture experiments, sand and soil in the ratio $1: 1$ was taken and autoclaved at $121^{\circ} \mathrm{C}$ for one hour. About $5 \mathrm{Kg}$ soil was filled in each pot $(23 \times 13 \times 17$ : upper diameter, basal diameter and height in $\mathrm{cm}$ ). The inoculums containing 200-250 spores were added at the rate of $20 \mathrm{gms} /$ pot. 9 sets of replicas were maintained. The experiment was repeated thrice.

\section{Each set consisted of six treatments namely:}

$\mathrm{N}$ - Normal plant without AM fungi

N1 - Normal plant inoculated with Glomus mosseae

N2 - Normal plant inoculated with Glomus fasciculatum

$R$ - Regenerated plant without AM fungi

R1- Regenerated plant inoculated with Glomus mosseae

R2 - Regenerated plant inoculated with Glomus fasciculatum

\section{Determination of mycorrhizal root colonization}

The percent infection of both normal and regenerated plants in each treatment and control were estimated $(16,17)$. Harvested plant roots were washed well in tap water. They were cut into segments of $1 \mathrm{~cm}$ and autoclaved in $10 \% \mathrm{KOH}$ at $120^{\circ} \mathrm{C}$ for 15 minutes. $\mathrm{KOH}$ was decanted and roots rinsed with water to remove $\mathrm{KOH}$. The roots were then acidified by the addition of $1 \% \mathrm{HCl}$ for 5 minutes. $\mathrm{HCl}$ was decanted with care taken not to wash with water because the specimens must be acidified for proper staining. For staining the sample roots segments, $0.05 \%$ trypan blue in lactoglycerol was added to the test tubes and simmered for 10 minutes in a hot water bath. The stain was decanted and the sample preserved in $50 \%$ glycerol/ lactoglycerol.
Randomly selected root pieces were mounted on slides in lactoglycerol, squashed, and examined under the microscope for mycorrhizal colonization.

\section{Percentage of mycorrhizal colonization calculated by the formula:}

$\%$ of mycorrhizal colonization $=$ No of root bits colonized

No of root bits taken for observation

\section{Estimation of mycorrhizal spores}

Extrametrical chlamydospores produced by the mycorrhizal fungus were estimated by wet sieving and decanting method (18). $50 \mathrm{mg}$ of representative soil samples from each treatment was suspended in $500 \mathrm{ml}$ quantity of water and stirred thoroughly. Resulting soil suspension was passed through sieves of 450, 300, 205, 105 and $45 \mu \mathrm{m}$ kept one below the other in the same order. The soil and the spores on the bottom two sieves were transferred on to a nylon mesh of a smaller pore size. The nylon mesh with spores on it was placed in a petriplate and the spores were counted under the microscope.

\section{Morphological observations on plant growth parameters}

Representative samples from each treatment and replications were uprooted and data recorded at 30 , 60 and 90 days after planting. They were thoroughly washed in running water to remove all adhering particles to the roots. The shoot length, root length, height of the plant, number of branches, number of nodes per branch, length of internode (from 4th to 6th node from the shoot apex), leaf length (from leaf tip to the base), leaf breadth and Biomass of plant (roots and shoots weighted separately for their fresh weight and shade dried for dry weight) were evaluated for normal, regenerated and VAM treated plants.

\section{Statistical Analysis:}

Completely randomized design (CRD) was followed for all experiments. Number of replicates for each treatment was 3 and each replicate consisted minimum of 10 explants. Values are expressed as mean \pm SD. Analysis of Variance (ANOVA - One way) was done and differences between treatments were determined using student's t test at $5 \%$ level of significance (19).

\section{Results and Discussion}

In vitro regeneration and plantlet development.

In the present investigation, BAP or TDZ with 2,4-D lead to callusing of the explants followed by development of shoots. Maximum number of indirect multiple shoots (Fig.1,2) were observed on MS + BAP $(4.44 \mu \mathrm{M})+\mathrm{GA} 3$ $(1.44 \mu \mathrm{M})+2,4-\mathrm{D}(2.26 \mu \mathrm{M})$. Influence of BAP on shoot growth is known in a number of medicinal plants $(20$, $21,22)$. Shoot elongation was achieved on medium 

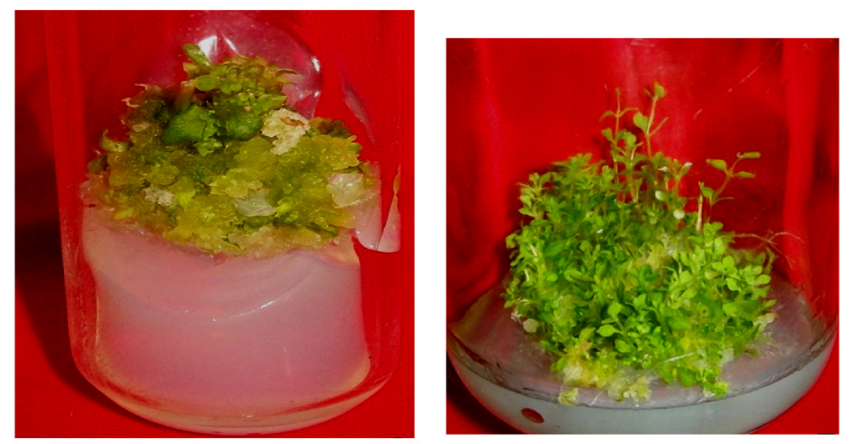

Fig 1: Indirect shoot regeneration Fig 2: Emergence of Multiple Shoots

Percent of mycorrhizal root colonization, number of vesicles and arbuscules and spore count in the rhizosphere in untreated and AMF treated normal and regenerated plants.

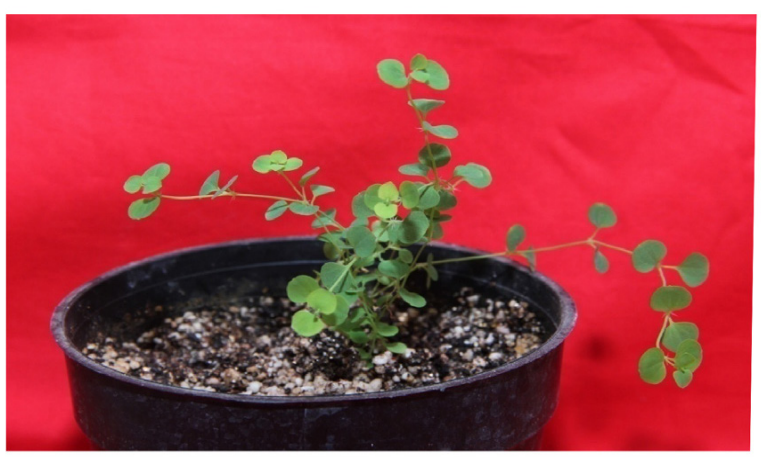

Fig 3: Regenerated plant of Drymaria cordata

containing GA3. MS + IBA $(0.49 \mu \mathrm{M})$ proved to be efficient in producing healthy and long roots in Drymaria. The in vitro regenerated plants showed successful acclimatization. (Fig. 3). Similar results were observed earlier in the same taxon (23). The efficiency of IBA in inducing in vitro roots has been reported by several workers $(24,25)$.

Percent of mycorrhizal root colonization, number of vesicles and arbuscules and spore count in the rhizosphere in untreated and AMF treated normal and regenerated plants.

After 90 days of Arbuscular mycorrhizal treatment, results showed a varied degree of spore population and mycorrhizal root colonization in all plants (Table 1). Significant percent colonization was observed in regenerated treated plants than in normal treated plants. $33.00 \pm 1.00 \%$ colonization was observed in Glomus fasciculatum treated regenerated plants with a significant increase in the number of vesicles and arbuscules. The maximum number of vesicles and arbuscules was observed to be $9.67 \pm 0.58$ and $25.00 \pm 1.00$ respectively in regenerated plants treated with $G$. fasciculatum. While G. mosseae treated normal and regenerated plants showed a less count. The highest percentage of colonization in regenerated plants may be due to early colonization by AM fungus or may be due to increased root cell membrane permeability and more hyphal penetration. The fungus having higher root colonization are better adapted for reabsorption of more nutrients and thus promote the growth of medicinal plants. Due to absence of mycorrhizal colonization, vesicles or arbuscules were not observed in the control or untreated normal and regenerated plants. There was a substantial increase in the spore count in the rhizosphere of $G$. fasciculatum treated regenerated plants after 90 days of inoculation. The spore count increased to $52.00 \pm 1.00$ in the rhizosphere of regenerated plants. Similar results showing an increase in the percentage colonization and spore count was observed in the in vitro grown plants of Withania somnifera and in a number of medicinal and vegetable plants $(26,27)$.

Shoot length, root length and plant height of untreated and AMF treated normal and regenerated plants:

It is evident from the results (Table 2), that AM inoculation significantly increased the shoot length, root length and plant height after 90 days of inoculation. Maximum shoot and root length was recorded in the $G$. fasciculatum treated regenerated plants which was found to be $69.23 \pm 0.68 \mathrm{~cm}$ and $22.50 \pm 0.50 \mathrm{~cm}$ respectively. G. mosseae treated regenerated and normal plants showed shoot and roots of shorter length. Corresponding to the increase in the length of the shoot and root, the plant height was found to be more in the regenerated plants treated with $\mathrm{G}$. fasciculatum. The maximum plant height was recorded to be $91.40 \pm 0.46 \mathrm{~cm}$. It was clearly evident from the results that $G$. fasciculatum treated regenerated plants have shown an enhanced shoot and root length leading to corresponding increase in plant height when compared to $G$. mosseae treated normal and regenerated plants. AM treated medicinal plants have shown improved growth and development as compared to control plants $(28,29)$.

Number of branches, number of nodes per branch, length of internode, leaf length and leaf breadth of un treated and AMF treated normal and regenerated plants

The regenerated plants of Drymaria cordata showed good response to AM funal inoculation. Corresponding to a significant increase in the height of the regenerated plants treated with $\mathrm{G}$. fasciculatum, the number of branches, number of nodes per branch, length of internode, length and breadth of leaf too showed enhanced growth (Table. 3, 4). After a period of 90 days, a maximum of $36.50 \pm 0.58$ branches, $30.33 \pm 0.58$ number of nodes and intermodal length of $4.63 \pm 0.06$ $\mathrm{cm}$ was observed in the regenerated plants treated with G. fasciculatum. G. mosseae inoculated normal plant and regenerated plants showed less growth. The micropropagated plants of Bacopa monnieri showed vigorous plant growth when inoculated with VAM fungi, which is in continuity with the present investigation (30).

The enhanced growth performance in regenerated 
Table 1: Effect of AMF association on percent of colonization, number of vesicles, arbuscules and spore count in normal and regenerated plants of Drymaria cordata

\begin{tabular}{|c|c|c|c|c|c|c|c|c|c|c|c|c|}
\hline \multirow[b]{2}{*}{ Treatments } & \multicolumn{4}{|c|}{ 30 DAYS } & \multicolumn{4}{|c|}{ 60 DAYS } & \multicolumn{4}{|c|}{90 DAYS } \\
\hline & $\% \mathrm{C}$ & $\begin{array}{c}\mathrm{V} \\
\text { (per cm } \\
\text { root) }\end{array}$ & $\begin{array}{c}\mathrm{A} \\
\text { (per cm } \\
\text { root) }\end{array}$ & $\begin{array}{c}\text { SP } \\
\text { (Per10 gm } \\
\text { soil) }\end{array}$ & $\% \mathrm{C}$ & $\begin{array}{c}\mathrm{V} \\
\text { (per cm } \\
\text { root) }\end{array}$ & $\begin{array}{c}\mathbf{A} \\
\text { (per cm } \\
\text { root) }\end{array}$ & $\begin{array}{c}\text { SP } \\
\text { (Per } \\
10 \text { gm } \\
\text { soil) }\end{array}$ & $\% \mathrm{C}$ & $\begin{array}{c}\mathrm{V} \\
\text { (per cm } \\
\text { root) }\end{array}$ & $\begin{array}{c}\mathbf{A} \\
\text { (per cm } \\
\text { root) }\end{array}$ & $\begin{array}{c}\text { SP } \\
\text { (Per } \\
10 \text { gm } \\
\text { soil) }\end{array}$ \\
\hline $\mathbf{N}$ & $0.00 \mathrm{e}$ & $0.00^{\mathrm{c}}$ & 0.00 & $0.00 \mathrm{e}$ & $0.00 \mathrm{e}$ & $0.00 \mathrm{e}$ & $0.00 \mathrm{~d}$ & $0.00 \mathrm{e}$ & $0.00 \mathrm{~d}$ & $0.00 \mathrm{~d}$ & $0.00 \mathrm{e}$ & $0.00 \pm 0.00 \mathrm{e}$ \\
\hline N1 & $4.00 \pm 1.00 \mathrm{~d}$ & $1.67 \pm 0.58 \mathrm{~b}$ & 0.00 & $9.67 \pm 0.58 \mathrm{~d}$ & $10.10 \pm 0.17 \mathrm{~d}$ & $4.67 \pm 0.58 \mathrm{~d}$ & $11.00 \pm 1.00 \mathrm{c}$ & $23.67 \pm 0.87 \mathrm{~d}$ & $20.67 \pm 0.58 \mathrm{c}$ & $6.13 \pm 0.58 \mathrm{c}$ & $18.56 \pm 0.58 \mathrm{~d}$ & $29.33 \pm 0.87 \mathrm{~d}$ \\
\hline N2 & $4.50 \pm 0.87 \mathrm{c}$ & $2.33 \pm 0.87 \mathrm{~b}$ & 0.00 & $11.67 \pm 0.58 \mathrm{~b}$ & $12.33 \pm 0.58 \mathrm{c}$ & $6.33 \pm 0.58 \mathrm{c}$ & $11.27 \pm 0.46 \mathrm{c}$ & $30.33 \pm 0.87 \mathrm{~b}$ & $21.00 \pm 0.00 \mathrm{c}$ & $8.00 \pm 1.00^{b}$ & $20.67 \pm 0.58 \mathrm{c}$ & $44.00 \pm 1.00^{b}$ \\
\hline $\mathbf{R}$ & $0.00 \mathrm{e}$ & $0.00^{\mathrm{c}}$ & 0.00 & $0.00 \mathrm{e}$ & $0.00 \mathrm{e}$ & $0.00 \mathrm{e}$ & $0.00^{\mathrm{d}}$ & $0.00 \mathrm{e}$ & $0.00^{\mathrm{d}}$ & $0.00^{\mathrm{d}}$ & $0.00 \mathrm{e}$ & $0.00 \pm 0.00 \mathrm{e}$ \\
\hline R1 & $6.33 \pm 0.58 \mathrm{~b}$ & $2.67 \pm 0.58^{\mathrm{a}}$ & 0.00 & $11.00 \pm 1.00 \mathrm{c}$ & $14.00 \pm 1.00^{b}$ & $8.00 \pm 1.00^{b}$ & $12.00 \pm 1.00^{b}$ & $27.33 \pm 1.15 \mathrm{c}$ & $24.50 \pm 0.87 \mathrm{~b}$ & $8.33 \pm 0.58 \mathrm{~b}$ & $23.00 \pm 1.00 \mathrm{~b}$ & $32.33 \pm 1.15 \mathrm{c}$ \\
\hline R2 & $8.33 \pm 0.58 \mathrm{a}$ & $3.33 \pm 1.15 \mathrm{a}$ & 0.00 & $14.33 \pm 0.58^{\mathrm{a}}$ & $15.93 \pm 0.12^{\mathrm{a}}$ & $9.33 \pm 0.58 \mathrm{a}$ & $14.17 \pm 0.76^{\mathrm{a}}$ & $33.33 \pm 1.15 \mathrm{a}$ & $33.00 \pm 1.00 \mathrm{a}$ & $9.67 \pm 0.58^{\mathrm{a}}$ & $25.00 \pm 1.00 \mathrm{a}$ & $52.00 \pm 1.00^{\mathrm{a}}$ \\
\hline CD (0.05) & 0.21 & 0.97 & 0.00 & 0.60 & 0.67 & 0.67 & 0.70 & \begin{tabular}{l|l}
0.74 \\
\end{tabular} & \begin{tabular}{l|}
0.48 \\
\end{tabular} & 0.48 & 0.54 & 0.68 \\
\hline
\end{tabular}

$\%$ C - Percent AM root colonization; V - Vesicles; A - Arbuscules, SP - Number of spores; Values represent Mean \pm SD; Means followed by the same letter are not significantly different by student's t test at $\mathrm{P}=0.05 . \mathrm{CD}=$ Critical Difference

Table 2: Effect of AMF association on shoot length, root length and plant height in normal and regenerated plants of Drymaria cordata.

\begin{tabular}{|c|c|c|c|c|c|c|c|c|c|}
\hline \multirow[b]{2}{*}{ Treatments } & \multicolumn{3}{|c|}{30 days } & \multicolumn{3}{|c|}{60 days } & \multicolumn{3}{|c|}{90 days } \\
\hline & $\begin{array}{c}\text { SL } \\
(\mathbf{c m})\end{array}$ & $\begin{array}{l}\text { RL } \\
\text { (cm) }\end{array}$ & $\begin{array}{l}\mathbf{P H} \\
\text { (cm) }\end{array}$ & $\begin{array}{c}\text { SL } \\
\text { (cm) }\end{array}$ & $\begin{array}{l}\text { RL } \\
\text { (cm) }\end{array}$ & $\begin{array}{l}\text { PH } \\
\text { (cm) }\end{array}$ & $\begin{array}{c}\text { SL } \\
\text { (cm) }\end{array}$ & $\begin{array}{l}\text { RL } \\
(\mathrm{cm})\end{array}$ & $\begin{array}{l}\mathbf{P H} \\
\text { (cm) }\end{array}$ \\
\hline $\mathbf{N}$ & $16.33 \pm 0.58 \mathrm{~d}$ & $5.93 \pm 0.12 \mathrm{~d}$ & $22.0 \pm 0.50^{\mathrm{f}}$ & $30.80 \pm 0.95^{\mathrm{f}}$ & $9.33 \pm 0.58 \mathrm{e}$ & $39.40 \pm 0.79^{f}$ & $51.17 \pm 0.76^{f}$ & $16.97 \pm 0.95 \mathrm{~d}$ & $68.17 \pm 0.76^{f}$ \\
\hline N1 & $23.17 \pm 0.76^{\mathrm{c}}$ & $7.13 \pm 0.32^{\mathrm{c}}$ & $30.17 \pm 0.76^{\mathrm{d}}$ & $37.33 \pm 0.76^{\mathrm{d}}$ & $9.67 \pm 0.29 \mathrm{e}$ & $46.63 \pm 0.64 \mathrm{~d}$ & $60.97 \pm 0.95^{\mathrm{d}}$ & $18.47 \pm 0.90^{\mathrm{c}}$ & $79.30 \pm 0.61^{\mathrm{d}}$ \\
\hline $\mathbf{N 2}$ & $24.93 \pm 0.51^{b}$ & $8.00 \pm 0.50^{b}$ & $34.17 \pm 0.76^{b}$ & $54.77 \pm 0.87 \mathrm{~b}$ & $12.33 \pm 0.29 \mathrm{~b}$ & $67.00 \pm 0.87 \mathrm{~b}$ & $66.10 \pm 0.36^{b}$ & $19.50 \pm 0.50^{\mathrm{b}}$ & $85.50 \pm 0.50^{\mathrm{b}}$ \\
\hline $\mathbf{R}$ & $22.47 \pm 0.93 \mathrm{c}$ & $6.33 \pm 0.29 \mathrm{~d}$ & $28.57 \pm 0.51 \mathrm{e}^{\mathrm{e}}$ & $35.80 \pm 0.26 \mathrm{e}$ & $10.50 \pm 0.50 \mathrm{~d}$ & $45.13 \pm 0.32 \mathrm{e}^{\mathrm{e}}$ & $55.00 \pm 0.10 \mathrm{e}$ & $18.27 \pm 0.55^{\mathrm{c}}$ & $72.63 \pm 0.64 \mathrm{e}$ \\
\hline R1 & $25.33 \pm 0.91^{b}$ & $8.33 \pm 0.58^{b}$ & $33.03 \pm 0.55^{\mathrm{c}}$ & $38.80 \pm 0.62 \mathrm{c}$ & $11.47 \pm 0.45^{\mathrm{c}}$ & $51.27 \pm 0.64 \mathrm{c}$ & $64.93 \pm 0.90^{\mathrm{c}}$ & $19.83 \pm 0.76^{b}$ & $83.83 \pm 0.76^{\mathrm{c}}$ \\
\hline R2 & $26.83 \pm 0.29 \mathrm{a}$ & $10.0 \pm 0.50^{\mathrm{a}}$ & $36.40 \pm 0.66^{a}$ & $56.30 \pm 0.52^{\mathrm{a}}$ & $15.33 \pm 0.58^{\mathrm{a}}$ & $71.43 \pm 0.93 \mathrm{a}$ & $69.23 \pm 0.68^{a}$ & $22.50 \pm 0.50^{\mathrm{a}}$ & $91.40 \pm 0.46^{\mathrm{a}}$ \\
\hline CD (0.05) & 0.83 & 0.47 & 0.73 & 0.81 & 0.53 & 0.84 & 0.58 & 0.83 & 0.73 \\
\hline
\end{tabular}

SL - Shoot length; RL - Root length; PH - Plant height; Values are the mean \pm SD; Means followed by the same letter are not

significantly different by student's t test at $\mathrm{P}=0.05$. $\mathrm{CD}=$ Critical difference

Table 3: Effect of AMF association on number of branches, number of nodes per branch and length of internode in normal and regenerated plants of Drymaria cordata.

\begin{tabular}{|c|c|c|c|c|c|c|c|c|c|}
\hline \multirow[b]{2}{*}{ Treatments } & \multicolumn{3}{|c|}{30 days } & \multicolumn{3}{|c|}{60 days } & \multicolumn{3}{|c|}{90 days } \\
\hline & B & NB & LIN (cm) & B & NB & LIN (cm) & B & NB & LIN (cm) \\
\hline $\mathbf{N}$ & $2.33 \pm 0.58^{b}$ & $5.57 \pm 0.51^{\mathrm{d}}$ & $3.33 \pm 0.58^{\mathrm{a}}$ & $12.33 \pm 0.58^{\mathrm{e}}$ & $8.67 \pm 0.58^{\mathrm{e}}$ & $3.33 \pm 0.29 b$ & $24.50 \pm 0.58^{f}$ & $15.17 \pm 0.76^{\mathrm{e}}$ & $4.03 \pm 0.06^{\mathrm{b}}$ \\
\hline N1 & $2.33 \pm 0.58^{b}$ & $6.57 \pm 0.51^{\mathrm{c}}$ & $3.43 \pm 0.4^{\mathrm{a}}$ & $18.50 \pm 0.50^{\mathrm{d}}$ & $9.83 \pm 0.76^{\mathrm{d}}$ & $3.47 \pm 0.06^{\mathrm{b}}$ & $26.0 \pm 0.58^{\mathrm{e}}$ & $17.17 \pm 0.76^{\mathrm{d}}$ & $4.13 \pm 0.15^{b}$ \\
\hline N2 & $2.67 \pm 0.58 \mathrm{a}$ & $7.33 \pm 0.58^{b}$ & $3.50 \pm 0.50^{\mathrm{a}}$ & $20.83 \pm 0.29 b$ & $10.83 \pm 0.29 c$ & $3.50 \pm 0.40^{b}$ & $31.0 \pm 0.58 \mathrm{c}$ & $23.00 \pm 0.50^{\mathrm{c}}$ & $4.23 \pm 0.06^{\mathrm{b}}$ \\
\hline $\mathbf{R}$ & $2.67 \pm 0.58^{\mathrm{a}}$ & $7.00 \pm 0.00^{b}$ & $3.67 \pm 0.76^{\mathrm{a}}$ & $20.17 \pm 0.76^{\mathrm{c}}$ & $8.83 \pm 0.29 \mathrm{e}$ & $4.07 \pm 0.12^{\mathrm{a}}$ & $27.50 \pm 0.58^{\mathrm{d}}$ & $16.83 \pm 0.29 \mathrm{~d}$ & $4.23 \pm 0.06^{\mathrm{b}}$ \\
\hline R1 & $2.67 \pm 0.58^{a}$ & $7.40 \pm 0.53 \mathrm{~b}$ & $3.70 \pm 0.75^{a}$ & $21.50 \pm 0.87^{b}$ & $15.17 \pm 0.76^{b}$ & $4.17 \pm 0.06^{\mathrm{a}}$ & $32.50 \pm 0.58^{b}$ & $20.83 \pm 0.76^{b}$ & $4.53 \pm 0.06^{\mathrm{b}}$ \\
\hline R2 & $3.00 \pm 0.00^{\mathrm{a}}$ & $8.17 \pm 0.76^{a}$ & $3.77 \pm 0.25^{\mathrm{a}}$ & $24.17 \pm 0.76^{\mathrm{a}}$ & $18.67 \pm 0.76^{\mathrm{a}}$ & $4.20 \pm 0.10^{\mathrm{a}}$ & $36.50 \pm 0.58^{a}$ & $30.33 \pm 0.58^{a}$ & $4.63 \pm 0.06^{\mathrm{a}}$ \\
\hline CD (0.05) & 0.61 & 0.62 & 0.71 & 0.76 & 0.71 & 0.25 & 0.67 & 0.68 & 0.94 \\
\hline
\end{tabular}

B - Number of Branches; NB - Number of nodes per branch; LIN - Length of internode; Values are the mean \pm SD; Means followed by the same letter are not significantly different by student's t test at $\mathrm{P}=0.05 . \mathrm{CD}=$ Critical Difference.

Table 4 : Effect of AMF association on leaf length and breadth in normal and regenerated plants of Drymaria cordata.

\begin{tabular}{|c|c|c|c|c|c|c|}
\hline \multirow[b]{2}{*}{ Treatments } & \multicolumn{2}{|c|}{ 30 days } & \multicolumn{2}{|c|}{60 days } & \multicolumn{2}{|c|}{90 days } \\
\hline & LL (cm) & LB (cm) & LL (cm) & LB (cm) & LL (cm) & LB (cm) \\
\hline $\mathbf{N}$ & $0.80 \pm 0.01^{b}$ & $0.95 \pm 0.01^{b}$ & $0.93 \pm 0.06^{b}$ & $1.03 \pm 0.06^{\mathrm{c}}$ & $1.07 \pm 0.06^{b}$ & $1.33 \pm 0.06^{b}$ \\
\hline N1 & $0.81 \pm 0.02^{b}$ & $1.10 \pm 0.02^{b}$ & $1.13 \pm 0.06^{\mathrm{a}}$ & $1.27 \pm 0.06^{\mathrm{b}}$ & $1.13 \pm 0.06^{\mathrm{b}}$ & $1.40 \pm 0.10^{\mathrm{b}}$ \\
\hline $\mathbf{N 2}$ & $0.87 \pm 0.06^{\mathrm{a}}$ & $1.23 \pm 0.06^{\mathrm{a}}$ & $1.13 \pm 0.06^{\mathrm{a}}$ & $1.33 \pm 0.06^{\mathrm{b}}$ & $1.17 \pm 0.06^{\mathrm{b}}$ & $1.53 \pm 0.06^{\mathrm{a}}$ \\
\hline $\mathbf{R}$ & $0.82 \pm 0.01 \mathrm{a}$ & $1.27 \pm 0.01 \mathrm{a}$ & $1.13 \pm 0.06^{\mathrm{a}}$ & $1.43 \pm 0.06^{\mathrm{a}}$ & $1.17 \pm 0.12 \mathrm{~b}$ & $1.50 \pm 0.00^{\mathrm{a}}$ \\
\hline $\mathbf{R 1}$ & $0.93 \pm 0.06^{\mathrm{a}}$ & $1.30 \pm 0.06^{\mathrm{a}}$ & $1.13 \pm 0.06^{\mathrm{a}}$ & $1.47 \pm 0.06^{\mathrm{a}}$ & $1.27 \pm 0.12^{\mathrm{a}}$ & $1.53 \pm 0.06^{\mathrm{a}}$ \\
\hline R2 & $0.97 \pm 0.06^{\mathrm{a}}$ & $1.33 \pm 0.06^{\mathrm{a}}$ & $1.17 \pm 0.06^{\mathrm{a}}$ & $1.50 \pm 0.00^{\mathrm{a}}$ & $1.37 \pm 0.12^{\mathrm{a}}$ & $1.57 \pm 0.06^{\mathrm{a}}$ \\
\hline CD (0.05) & 0.15 & 0.17 & 0.18 & 0.10 & 0.18 & 0.08 \\
\hline
\end{tabular}

LL - Length of leaf from tip to base; LB - Leaf breadth.

Values are the mean $\pm \mathrm{SD}$; Means followed by the same letter are not significantly different by student's $\mathrm{t}$ test at $\mathrm{P}=0.05$. $\mathrm{CD}=\mathrm{Critical}$ difference

Table 5: Effect of AMF association on fresh weight and dry weight in normal and regenerated plants of Drymaria cordata

\begin{tabular}{|c|c|c|c|c|c|}
\hline \multirow{2}{*}{ Treatments } & \multicolumn{2}{|c|}{ 30 days } & \multicolumn{2}{|c|}{ 60 days } & \multicolumn{2}{|c|}{ 90 Days } \\
\cline { 2 - 7 } & $\begin{array}{c}\text { Fresh } \\
\text { weight (gm) }\end{array}$ & $\begin{array}{c}\text { Dry } \\
\text { weight (gm) }\end{array}$ & $\begin{array}{c}\text { Fresh } \\
\text { weight (gm) }\end{array}$ & $\begin{array}{c}\text { Fresh } \\
\text { weight (gm) }\end{array}$ & $\begin{array}{c}\text { Dry } \\
\text { weight (gm) }\end{array}$ \\
\hline $\mathbf{w e i g h t}(\mathbf{g m})$
\end{tabular}

Values are mean \pm SD Means followed by the same letter are not significantly different by student's $t$ test at $\mathrm{P}=0.05$. CD - Critical difference 
plants of Drymaria cordata was due to mycorrhization of $\mathrm{G}$. fasciculatum. The length and breadth of the leaf observed in regenerated plants treated with $G$. fasciculatum was recorded as $1.37 \pm 0.12 \mathrm{~cm}$ and $1.57 \pm 0.06$ respectively. There was a significant reduction in the leaf area in the plants treated with G.mosseae as well as in untreated plants. The present results are in the same line with the results observed in AM inoculated Solanum lycopersicum, where G. fasciculatum significantly enhanced the morphological features (31).

Fresh weight and dry weight of untreated and AMF treated normal and regenerated plants.

Plant biomass is an important parameter which directly reflects the efficiency of particular fungus. The fresh and dry weight of the inoculated regenerated plants were found to be maximum and significant than that of untreated plants (Table 5). After 90 days of inoculation with G. fasciculatum, the fresh and dry weights of regenerated plants were observed to be $15.108 \pm 0.26 \mathrm{gm}$ and $3.878 \pm 0.13 \mathrm{gm}$ respectively. From the results it was revealed that due to enhanced root and shoot length, internode length and number of branches there was an corresponding increase in the plant biomass in regenerated plants treated with $G$. fasciculatum than other treatments. At the end of 90 days the plants produced numerous floral buds which also contributed to its biomass. Similar effectiveness of $G$. fasciculatum on the growth and performance of normal and regenerated plants of Andrographis paniculata were studied (32). Effect of root colonization by arbuscular mycorrhizal fungi on growth, productivity and disease resistance has also been investigated in rice crop (33). The most important contribution of these AM fungi to plant growth is due to extra-radical hyphal absorption of phosphorus and other elements and transfer to the root tissues. The enhanced quantity of available phosphorus and levels of exchangeable potassium and magnesium in AM treated plant soil would certainly mean better growth in terms of number of leaves, branches and biomass in AM treated plants than control.

\section{Conclusion}

Traditional people have developed remedies for curing number of ailments due to their association with nature over a long period of time. Drymaria cordata (L.) Willd. Ex Roem. \& Schult. (Caryophyllaceae) is one such folklore herb of considerable medicinal importance. Arbuscular mycorrhizal studies have importance in agriculture and land reclamations. Plant roots provide an ecological niche for many of the microorganisms that abound in soil. In natural ecosystems much of the terrestrial plants associate with root colonizing mycorrhizal fungi, which improve the fitness of both the fungal and plant associates. From the studies undertaken, the role of AMF on Drymaria is indicative of the potential that this association is apparent for improved production. AMF treated regenerated plants have shown significant results compared to untreated plants. These results suggest that $\mathrm{G}$. fasciculatum are better symbionts for inoculating Drymaria cordata. Due to wide use of the plant in folklore medicines, from the study, we can conclude that, treating Drymaria cordata with Arbuscular mycorrhizal fungi has enhanced their biomass production and quality and thus can contribute to the formulations of herbal medicines and pharmacy.

\section{References}

1. Szymon Zubek Janusz Blaszkowski. (2009) Medicinal plants as hosts of arbuscular mycorrhizal fungi and dark septate endophytes. Phytochem. Rev, 8:571-580.

2. Khatun, S. (2020). Effect of Glomus fasciculatum on nutrient uptake and growth of a medicinal plant Coleus forskohlii. European Journal of Medicinal Plants, 31(4), 25-37.

3. Gupta, R. and Mukerji, K.G. (2003). Association of VAM in Indian weeds. Compendium of Mycorrhizal Research, I: 187-202.

4. Jordan, N., Vatovec, C. and Huerd, H. (2005). Responsiveness of certain agronomic weed species to arbuscular mycorrhizal fungi. Renewable Agricul. and food Sys, 20: 181 189.

5. Zou, Y. N., Srivastava, A. K., Wu, Q. S. (2016). Glomalin: a potential soil conditioner for perennial fruits. Int. J. Agric. Biol, 18: 293-297.

6. Thirkell, T. J., Charters, M. D., Elliott, A. J., Sait, S. M., Field, K. J. (2017). Are mycorrhizal fungi our sustainable saviours considerations for achieving food security. J. Ecol, 105: 921-929.

7. Brundrett, M.C. (2009). Mycorrhizal associations and other means of nutrition of vascular plants: understanding the global diversity of host plants by resolving conflicting information and developing reliable means of diagnosis. Plant and Soil, 320:3777.

8. Rouphael, Y., Franken, P., Schneider, C., Schwarz, D., Giovannetti, M., Agnolucci, M. (2015). Arbuscular mycorrhizal fungi act as bio-stimulants in horticultural crops. Sci. Hort, 196: 91-108.

9. Gashgari, R., Selim, S., Abdel-Mawgoud, M. et al. (2020). Arbuscular mycorrhizae induce a global metabolic change and improve the nutritional and health benefits of pennyroyal and parsley. Acta Physiol Plant, 42: 102.

10. Naheeda Begum, Muhammad Abass Ahanger, 
Sajjad Raza, Muhammad Ishfaq Khan, Muhammad Ashraf, Nadeem Ahmed and Lixin Zhang. (2019) Role of arbuscular mycorrhizal fungi in plant growth regulation: Implications in abiotic stress tolerance. Front. Plant Sci, 10: 1068.

11. Kapoor, R., Sharma, D. and Bhatnagar, A.K. (2008). Arbuscular Mycorrhizae in micropropagation systems and their potential applications. Scientia Horticulturae, 116: 227239.

12. Adeyemi, O.O., Akindele, A.J., Ndubuisi, N. (2008). Anti-inflammatory activity of Drymaria cordata extract. Journal of Natural Remedies, 8(1): 93-100.

13. Akindele, A.J., Ibe, I. F., Adeyemi, O.O. (2012). Analgesic and antipyretic activities of Drymaria cordata (Linn.) Willd (Caryophyllaceae) extract. African Journal of Traditional Complementary and Alternative Medicine, 9(1): 25-35.

14. Telefo, P.B., Lienou, L.L., Yemele, M.D., Lemfack, M.C., Mouokeu, C., Goka, C.S., Tagne, S.R., and Moundipa, F.P. (2011). Ethnopharmacological survey of plants used for the treatment of female infertility in Baham, Cameroon. J Ethnopharmacol, 136(1):178-187.

15. Hsieh, P.W., Chang, F. R., Lee, K. H., Hwang, T. L., Chang, S. M. and Wu, Y. C. (2004). A new anti-HIV alkaloid, drymaritin, and a new C glycoside flavonoid, diandraflavone, from Drymaria diandra. Journal of Natural Products, 67(7): 1175-1177.

16. Phillips, J. and Hayman, D.S. (1970). Improved procedures for clearing roots and staining parasitic and vesicular arbuscular mycorrhizal fungi for rapid assessment of infection. Trans. Br. Mycol. Soc, 55: 158-61.

17. Kormanik, B. T. Bryan, W.C, and Schultz, R.C. (1980). Methods for staining roots with trypan blue for assessing mycorrhizal colonization (Phillips and Hayman, 1970 with modifications). Can. J. Microbiol, 26: 536-538.

18. Gerdmann, J.W. and Nicolson, T.H. (1963). Spores of mycorrhizal endogone species extracted from soil by wet sieving and decanting. Trans. Brit. Mycol. Soc, 46: 235-244.

19. Silva, F.A.B, Pereira, L.A.R. and Silveira, C.E.S. (2008). Micropropagation of Alibertia edulis Rich. Brazilian Archives of Biology and Technology, 51(6): 1103-1114.
20. Bhaskar Sarma, Bhaben Tanti. (2017) In vitro regeneration of plantlets from nodal explants of Aristolochia saccata and Aristolochia cathcartii. European Journal of Biological Research, 7 (3): 191201.

21. Joshi, M, Dhar, U. (2003) In vitro propagation of Saussurea obvallata (DC.) Edgew. - an endangered ethno religious medicinal herb of Himalaya. Plant Cell Reports, 21: 933-939. 11.

22. Sharma, N., Chandel, K.P.S. and Paul, A. (1993) In vitro propagation of Gentiana kurroo - an indigenous threatened plant of medicinal importance. Plant Cell Tissue Organ Cult, 34: 307-309.

23. Tejavathi, D.H and Indira, M.N. (2013). Regeneration of shoots from leaf callus cultures of Drymaria cordata (L.) Willd. ex Roem. and Schult. Indian Journal of Fundamental and Applied Life Sciences, 3(1): 111-115.

24. Fengyun Wang , Xiaowei Xin, Hao Wei, Xiaohui Qiu and Boling Liu. (2020) In Vitro Regeneration, Ex Vitro Rooting and Foliar Stoma Studies of Pseudostellaria heterophylla (Miq.) Pax. Agronomy, 10: 949.

25. Rizwan Rafique, Balquees Fatima, Salman Mushtaq, Muhammad Shahid Iqbal, Misbah Rasheed, Muhammad Ali and Syed Zia U, Hasan. (2012). Effect of indole-3-butyric acid (IBA) on in vitro root induction in dendrobium orchid (Dendrobium sabin H.) African Journal of Biotechnology, 11(20): 46734675.

26. Raveesha, H.R. and Manjunath Reddy, G.R. (2014). Influence of Glomus species on enhancement of metabolites in in vitro regenerated Withania somnifera (L.) Dunal. International Journal of Development Research. 14(12): 2592-2597.

27. Poonam Verma1, Sagar Barle, Mridul Shakya and Sardul Singh Sandhu. (2019). Assessment of root colonization by VAM fungi in vegetable plants in Central India. Global Journal of Bioscience and Biotechnology, 8(1): 60-66.

28. Karthikeyan, B., Joe, M.M. and Jaleel, C.A. (2009). Response of some medicinal plants to vesicular arbuscular mycorrhizal inoculations. Journal of Scientific Research, 1(1): 381-386.

29. Burni, T., Hussain, F. and Sharif, M. (2013). Effect of arbuscular mycorrhizal fungi on essential oils of two pharmaceutically important Mentha species in marginal soils. Pak. J. Bot, 45(1): 293-296. 
30. Tejavathi, D.H. and Rao, N.N. (1998). Comparative studies between normal and tissue cultured plants of Bacopa monnieri (L.) Pennell. In, Khan IA, Khannum A (Eds.) Role of Biotechnology in medicinal and aromatic plants I, Ukaaz publication, Hyderabad, India, pp 239247.

31. Kavatagi, P.K. and Lakshman, H.C. (2012). Effect of arbuscular mycorrhizal fungi for their symbiotic efficiency on two varieties of Solanum lycopersicum. L. International Journal of Pharma and Biosciences. 3(3): 1007-1017.
32. Tejavathi, D.H., Anitha, P., Murthy, S.M. and Nijagunaiah, R. (2011). Effect of AM fungal association with normal and micropropagated plants of Andrographis paniculata Nees on Biomass, primary and secondary metabolites. International Research Journal of Plant Science, 2(12): 338-348.

33. Campo, S., Martín-Cardoso, H., Olivé, M. et al. (2020). Effect of root colonization by arbuscular mycorrhizal fungi on growth, productivity and blast resistance in rice. Rice, 13: 42. 